\title{
Using Self- monitoring Strategy to improve English Spelling Accuracy and Self- efficacy of Primary School Pupils with ADHD
}

\author{
Dr. Jehan Mahmoud El-Bassuony \\ Assistant Professor, Department of Curriculum \& Instruction \\ Faculty of Education \\ Port Said University
}

Egypt

The purpose of this study was to investigate the effectiveness of a treatment based on self-monitoring strategy in developing English spelling accuracy and self- efficacy of EFL primary school pupils with attention deficit hyperactivity disorder (ADHD). The sample of the study consisted of one hundred nineteen fourth grade pupils at Mohamed Hassan Alzayat primary school in Damietta Governorate. The two groups progress-post test quasi-experimental design was used. The instruments of the study included the diagnostic battery of children with ADHD prepared by Abd Alrahman Said Soliman and Mahmoud Mohamed El-Tantawe, the progress- post spelling accuracy tests and the pre- post spelling self-efficacy scale. The results of the study revealed that the self-monitoring strategy significantly developed English spelling accuracy and self- efficacy of both ADHD pupils and their normal peers.

Keywords: self-monitoring strategy, English spelling accuracy, spelling self- efficacy, primary school, pupils with ADHD. 


\section{Introduction}

Historically, the ability to control and regulate one's behavior and academic performance has been considered a desirable characteristic. One of the strategies that can help students attain such characteristic is selfmonitoring. According to Schunk (2001), self-monitoring is considered to be one of the first steps to self-regulated behavior. It is defined as a critical self-regulation process, as it affects both behavior and academic performance (Shapiro, Durnan, Post, \& Levinson, 2002). It can include an evaluation component where the student actively obtains feedback and records progress towards a standard (Cooper, Heron, \& Heward, 2007). Furthermore, self-monitoring is important as a student-directed strategy that can promote independence, motivation, engagement, self-reliance and self-determination to increase learning (Agran, Sinclair, Alper, Cavin, Wehmeyer, \& Hughes, 2005).

English spelling is a complicated matter for many students since many interrelated skills are involved. Spelling involves the integration of several skills including knowledge of phonological representations, grammatical and semantic knowledge, as well as the formulation of analogies with words in visual memory and the knowledge of orthographic rules and conventions (Pijper, 2003). As a result, spelling words correctly when writing is a challenge for many individuals, especially students with special needs (Preast, 2009). In addition, research indicates that active practice and use of an efficient, systematic technique for studying unknown words improve spelling performance (Graham, 1999). Furthermore, teaching students to self-monitor their spelling study will do little to 
improve their performance if they do not know how to learn unknown words.

Self-efficacy is also an important factor in school performance and success. Students with high self-efficacy expend more effort in school, persist with tasks in the face of challenges, set challenging goals for themselves, and have better academic skills (Pajares, 2006). Moreover, self-efficacious students are more likely to be better self-regulators, engaging in behaviors that are crucial to academic success like selfmonitoring and self-evaluation (Klassen \& Usher, 2010). Self-efficacy is also a domain-specific phenomenon as high self-efficacy in one area will not necessarily implicate high self-efficacy in another area (Bandura, 1997). As a result, the beliefs that learners develop about their spelling capabilities help determine what they do with the knowledge about spelling and the skills they possess.

On the other hand, attention deficit hyperactivity disorder (ADHD) students have certain symptoms that might hinder their academic progress. According to American Psychiatric Association (2000), ADHD students are characterized by developmentally inappropriate inattentive and/or hyperactive/impulsive symptoms. Furthermore, as Barkley (1997) states, children with ADHD are often impersistent while engaged in activities requiring self-regulation and find delay of gratification challenging. The daily performance of these students on classroom tasks and homework is typically inconsistent and below that of their peers; up to $80 \%$ of students with ADHD have been found to exhibit academic performance problems (DuPaul \& Stoner, 2003). These challenges draw the attention to the significance of using different programs and strategies like self-monitoring 
to help ADHD learners spell new English vocabulary accurately and at the same time develop their spelling self-efficacy.

\subsection{Context of the problem}

Spelling words correctly when writing is a challenge for many individuals, especially students with special needs. Native and non-native learners have difficulties in learning how to spell English words. In an EFL context, spelling English words is often perceived as a tedious and laborious process. One of the reasons that makes English spelling such a difficult skill to acquire is that there is no direct relationship between sounds and letters in English.

Though primary stage students in Egypt are often involved in different spelling tasks, the performance of many students in these tasks is not satisfactory. As a general supervisor of teaching practice at the primary stage, the researcher observed that students found difficulty in spelling many English vocabulary items in their weekly spelling tests and as a result their spelling self-efficacy is low. In addition, researchers affirmed that there is a problem related to the poor achievement of Arab pupils in English spelling (Abu Ghazalah, 2010; Al Jarf, 2008; Aljayousi, 2011) and more specifically the primary stage pupils in Egypt (Nassar, 2004) and that negatively affects their spelling self- efficacy.

Of course this is a serious problem especially for ADHD learners who are characterized by a level of impulsivity, activity and attention that are not adequate for the development age. They find it difficult to regulate their behaviour and adjust to the rules expected for their age and this loss of self-regulation impairs their ability to spell English words accurately. In addition, some school teachers considered ADHA pupils as trouble makers 
who should be punished all the time in order to keep discipline in the class. Instead they should help them use different strategies to regulate their behaviour and consequently improve their academic performance.

As a result, how teachers present the spelling of new vocabulary is just one side of the problem, the other side is how they help their pupils study the spelling of these vocabulary items. Although the effectiveness of self-monitoring strategy in developing academic performance of at risk students is well established (Brooks, Todd, Tofflemoyer, \&Horner, 2003; Gureasko-Moore, DuPaul, \& White, 2007; Harris Friedlander, Saddler, Frizzelle, \& Graham, 2005; Rock, 2005; Rock \& Thead, 2007), no studiesas far as the researcher knows- investigated the effect of self-monitoring strategy on improving English spelling accuracy and self-efficacy of primary school pupils with ADHD.

\subsection{Statement of the problem}

The problem of the study can be identified in the weak performance of EFL primary stage pupils with ADHD concerning their English spelling accuracy and low spelling self-efficacy. Hence, this study sought to find answers to the following main question:

What is the effectiveness of using self-monitoring strategy in improving English spelling accuracy and self-efficacy of primary school pupils with ADHD?

The following sub-questions were also answered:

1- What is the level of primary school pupils with ADHD in English spelling accuracy?

2- To what extent do primary school pupils with ADHD possess English spelling self- efficacy? 
3- What are the features of a treatment based on self-monitoring strategy to develop English spelling accuracy and self- efficacy vocabulary of primary school pupils with ADHD?

4- How far is using self-monitoring strategy effective in improving English spelling accuracy of primary school pupils with ADHD?

5- How far is using self-monitoring strategy effective in improving English spelling self-efficacy of primary school pupils with ADHD?

\subsection{Hypotheses of the study}

Based on the discussion of literature and related studies, the following hypotheses were derived:

1- There would be a statistically significant difference between the mean scores of the experimental group and the control group on the progress spelling accuracy test in favour of the former.

2- There would be a statistically significant difference between the mean scores of the experimental group and the control group on the post spelling accuracy test in favour of the former.

3- There would be a statistically significant difference between the mean scores of the progress spelling accuracy test and post spelling accuracy test for the experimental group in favour of the latter.

4- There would be a statistically significant difference between the mean scores of the experimental group and the control group on the post self-efficacy scale in favour of the former.

5- There would be a statistically significant difference between the mean scores of the pre self-efficacy scale and post self-efficacy scale for the experimental group in favour of the latter. 


\subsection{Purpose of the study}

The purpose of the study was twofold:

1- Investigating the effectiveness of using self-monitoring strategy in developing English spelling accuracy of primary school pupils with ADHD.

2- Investigating the effectiveness of using self-monitoring strategy in developing English spelling self-efficacy of primary school pupils with ADHD.

\subsection{Significance of the study}

The significance of the study stems from the following considerations:

1- The progress spelling accuracy test, the post spelling accuracy test and the spelling self-efficacy scale might be beneficial to EFL researchers and curriculum designers.

2- The study might provide guidelines upon which further strategies may be used to develop English spelling accuracy and self-efficacy of primary school pupils with ADHD.

3- The study might draw the attention of educators to develop specific interventions for pupils with ADHD.

\subsection{Limitations of the study}

Since it was beyond the limits of a single study to consider a wide range of factors, this study was restricted to:

1- A selected number of vocabulary items in Time For English 4, the first term.

2- A limited duration for implementing the treatment (ten weeks).

3- One hundred nineteen fourth grade pupils at Mohamed Hassan Alzayat primary school in Damietta Governorate. 


\subsection{Definition of terms}

\section{Self-monitoring strategy}

According to Loftin, Gibb, and Skiba (2005, p. 3), self-monitoring strategies are individualized plans used to increase independent functioning in academic, behavioral, self-help, and social areas.

Self-monitoring is the practice of observing and recording one's own academic and social behaviors (Vaughn, Bos, \& Schumm, 2000).

In the present study, self-monitoring is defined as a strategy that helps the pupils to observe and record their progress in English spelling of specific vocabulary items from the prescribed text book "Time for English, 4" to improve their spelling accuracy and self-efficacy.

\section{Spelling accuracy}

Simmons (2007, p. 18) defines spelling as the ability to recognize, recall, reproduce, or obtain orally or in a written format the correct sequence of letters.

Spelling is the ability to form words by placing the letters of the alphabet in accepted and accurate arrangements so other literate people can easily recognize those words in their printed forms"(Smith, Pest, \& Coomber, 2001, p. 7).

According to Alber and Walshe (2004, p.56), spelling is writing the word using the correct letters in the correct sequence.

In the present study, spelling accuracy is defined as the ability of ADHD pupils to encode words from "Time for English 4, first term" in a written form as a result of a systematic study of the target words. 


\section{Spelling self-efficacy}

According to Bandura (1994, p.77), self-efficacy is defined as people's beliefs about their capabilities to produce designated levels of performance that exercise influence over events that affect their lives.

Bandura (1997, p. 3) adds that self-efficacy is "beliefs in one's capabilities to organize and execute the courses of action required to produce given attainments."

Shell, Colvin and Brunng $(1995,386)$ describes self-efficacy as "a confidence in one's capability for organizing and implementing the cognitive, behavioral, or social skills necessary for successful performance of a task."

It refers to specific judgments of specific tasks, such as whether one is capable of reading a specific book, rather than a global judgment, such as being a good reader (Walker, 2003, p. 174).

In the present study, spelling self-efficacy is defined as the beliefs that ADHD pupils have about their capabilities in performing specific spelling tasks as measured by spelling self-efficacy scale.

\section{Attention deficit hyperactivity disorder (ADHD)}

ADHD is a chronic and debilitating condition that is characterized by developmentally inappropriate inattentive and/or hyperactive/impulsive symptoms (American Psychiatric Association, 2000).

In the present study, ADHD learners are defined as pupils who engage in behaviors often characterized as inattentive, hyperactive, or impulsive as measured by the diagnostic battery of children with ADHD. 


\section{Review of literature}

The following section sheds more light on the main variables of this study which are self-monitoring strategy, English spelling accuracy, spelling self-efficacy, and ADHD learners.

\subsection{Self-monitoring strategy}

Self-monitoring is one of the self- regulation strategies. It is defined as a self-management procedure whereby a person systematically observes his or her own behaviour and then records the occurrence or nonoccurrence of a target behaviour (Ganz, 2008; Gulchak, 2008). In other words, it consists of self-assessment and self-recording. Self-monitoring is also practical since it encourages more self-regulation and less teacherdirected support for behaviours that interfere with learning. A potential classroom benefit of using a self-monitoring procedure is that teachers can spend more time on instruction and less time managing students' off-task and inappropriate behaviours (Ganz \& Sigafoos, 2005).

Self-monitoring strategy can help students overcome organizational and academic problems. According to Hoff and DuPaul (1998), selfmonitoring interventions equip students to recognize and keep track of their own behavior. They are among the most flexible, useful, and effective strategies for students with academic and behavioral difficulties (Mitchum, Young, West, \& Benyo, 2001). Self-monitoring is useful for students from preschool to adulthood and can be taught to individuals at a variety of levels of cognitive functioning. Self-monitoring interventions foster independent functioning, which allows individuals with disabilities to rely less on prompts from others (Koegel, Koegel, Harrower, \& Carter, 1999). 
Concerning self-monitoring and students at risk, it is one of the most frequently used behavior modification methods in education (Reid, Trout, $\&$ Schartz, 2005). Self-monitoring interventions can typically be classified into two broad categories: self-monitoring of on-task behavior or of a more specific performance like number of math problems accurately completed (Harris et al., 2005; Rafferty \& Raimondi, 2009). Self-monitoring interventions have shown positive outcomes for students with a wide variety of disabilities, such as learning disabilities, speech and language impairments, mild-to-moderate intellectual disabilities, emotional and/or behavioural disorders and ADHD (Reid, 1996).

Academic success and self-regulation behaviours are linked. Teachers expect students to self-regulate organisational behaviours; however, many students with disabilities often struggle to perform basic classroom survival skills (Snyder \& Bambara, 1997). Rather than focusing on reducing a student's undesired behavior, self-monitoring strategies develop skills that lead to an increase in appropriate behavior. When selfmonitoring skills increase, corresponding reductions in undesired behaviors often occur, even without direct intervention (Koegel, Koegel, Harrower, \& Carter, 1999).

In addition, self-monitoring has been studied across a variety of diverse behaviours. For instance, it has been shown to be an effective intervention to address a wide range of adaptive behavioural deficits including distractibility, impulsivity, non-compliance and aggression (Levendoski \& Cartledge, 2000), as well as for organisational and academic problems with classroom preparedness (Creel, Fore, Boon, \& Bender, 2006), engagement (Amato-Zech, Hoff, \& Doepke, 2006; 
Crawley, Lynch, \& Vannest, 2006), task completion and academic performance (Gureasko-Moore et al., 2007; Rock \& Thead, 2007).

Moreover, a number of studies about students with learning disabilities have shown that self-monitoring procedures have the potential to increase elementary and middle school students' on-task behaviours, academic skills and compliance to classroom-preparedness skills. For example, Rock (2005) examined the effects of a self-monitoring procedure on the academic engagement and problem behaviours of elementary students with and without disabilities. Results indicated that the strategy was effective for increasing academic engagement and decreasing problem behaviours. However, there were some inconsistencies with students' productivity and accuracy, as in most cases productivity increased but accuracy rates were variable. Amato-Zech, Hoff, and Doepke (2006) carried that line of research further. They indicated that using a tactile selfmonitoring prompt (MotivAider) increased levels of on-task behaviour during mathematics sessions of elementary students with disabilities.

In summary, the research represents self-monitoring as a flexible, adaptable intervention that can assist students in successfully managing their own behaviour, organisation and academic learning. The most recent studies have revealed the value of self-monitoring to improve classroom preparedness, on-task behaviour or engagement, and academic productivity and performance. It also proved to be effective for students with and without learning disabilities.

\subsection{English spelling accuracy}

Spelling is an extremely important aspect of the English curriculum, for both native and non-native speakers of English. It refers to "the ability 
to form words by arranging letters in a proper order." (Larson, Hammill, \& Moats, 1999, p. 33). Spelling is also defined as the knowledge of orthography, which is the system of symbols and rules used to represent spoken language in writing (Willett \& Gardiner, 2009, p. 4). Dehham and Mohmmed (2008, p. 3) add that spelling is the formation of words by using letters, orthographically; a combination of letters representing a word. It is also the ability to write words correctly depending on the memory.

In addition, spelling is the starting point for developing literacy skills. Gentry (1997, p. 33) argues that acquiring spelling knowledge in early stage, primary schools, opens the door to early literacy and beginning reading. When young learners begin to learn the letters of the alphabet and the sounds each letter makes, they are acquiring knowledge of the alphabetic system, as well as knowledge they can use toward spelling words. Spelling requires matching the sounds of language with the appropriate letters in order to accurately and reliably conveys a message (Wanzek, Vaughn, Wexler, Swanson, Edmonds, \& Kim, 2006). It also requires a fully specified memory for a word $\square$. Memories are established by looking closely, thinking about the details in words, understanding word structure, and developing motor habits for writing (Moats, 2010).

Essentially, English orthographic or spelling knowledge emerges in two ways: (a) through the ability to recognize and map spelling patterns to corresponding sound patterns at the phoneme, syllable, and word levels; and (b) through repeated exposures to the words (Caravolas, Hulme, \& Snowling, 2001; Templeton \& Morris, 2000). Ehri (2005) adds that word recognition fluency emerges as well-formed spelling representations become tightly connected or bonded to corresponding phonological and 
semantic forms. In other words, well-learned word spellings (i.e., sight vocabulary) are established in memory in graphic form and automatically recalled when they are encountered during reading.

In general, the L1 research on English spelling development shows that spelling skills emerge in stages or phases characterized by an early reliance on phonological codes to map sounds to letters and a later reliance on orthographic and phonological codes that map sounds and spelling patterns to words (Ehri \& Snowling, 2004). Early alphabetic spelling abilities at around the first grade generally involve basic letter-to-sound mapping skills in what can be referred to as the early alphabetic stage (Ehri, 2005) or the letter-name stage (Templeton \& Morris, 2000). The next general phase of English spelling development involves the ability to discover and acquire syllable-level-spelling patterns (Freeman \& Freeman, 2004). The final spelling phase in English incorporates derivational morphology into spelling patterns of multi-syllable words composed of root morphemes and derivational affixes (Ganske, 1999).

English spelling plays an important role in both native and foreign language learning contexts. Snow, Griffin, and Burns (2005, p. 86) summarize the real importance of spelling for reading as follows: "Spelling and reading build and rely on the same mental representation of a word. Knowing the spelling of a word makes the representation of it sturdy and accessible for fluent reading." In fact, Ehri and Snowling (2004) found that the ability to read words "by sight" (i.e. automatically) rests on the ability to map letters and letter combinations to sounds. Fender (2008) indicates that difficulties acquiring English spelling knowledge not only affect word recognition skills but also constrain ESL reading skills. Many researchers 
subscribe to the notion that English word recognition fluency is a function of spelling knowledge (Berninger et al., 2002; Perfetti \& Hart, 2001; Templeton \& Morris, 2000). Incomplete or inaccurate spelling representations or knowledge will result in less efficient, and in some cases, less accurate word recognition skills (Burt \& Tate, 2002).

English spelling is in no doubt a complicated matter and learners around the world have trouble getting the letters right (Solati, Sazalie, \& Che, 2008, p. 1). Within the context of English as a foreign language, it has been observed that students have serious problems in writing. Spelling is one such area where students seem to struggle (Meriem, 2010, p. 2). One of the reasons of such difficulty is that there are forty-four sounds and only twenty-six letters to represent them. That means knowing the pronunciation of a word does not enable one to predict its spelling with confidence. Another reason is that English is not a phonetic language, it is not written as it is spoken nor does it have closer phoneme-grapheme correspondence. Therefore, spelling difficulties are expected to rise for students learning English as a foreign language (Hasan, 2000, p. 3).

As for Arab learners, English spelling represents a much more complicated problem. The greatest difficulty encountered by Arab students arises from the irregular spelling system of English compared with the greater regularity of the predominantly phonetic script of Arabic (Kharma \& Hajjaj, 1989, p. 56). Awad (2010, p. 4) argues that English and Arabic have two different alphabets and differ significantly in terms of the complexity and systematicity of the spelling system. The fact that English spelling is more complex than that of Arabic, this is expected to pose 
several spelling difficulties for Arab students particularly in the early stages of spelling development (Al Jarf, 2008, p. 10).

Studies have shown that different activities and strategies can be effective in developing English spelling, Nassar (2004) revealed that Multiple Intelligences Theory based activities improved primary pupils' English spelling. Mesmeh (2012) investigated the effect of using the Cover, Copy and Compare (CCC) strategy for teaching spelling on the ninth graders' acquisition of spelling. It also examined the long-term effect of the strategy on the retention of the correct spelling. The results of this study confirmed the effectiveness of CCC strategy.

It is obvious that spelling is one of the most difficult areas in English language especially for Arab learners. Research proved that spelling enhances students' word recognition, reading and writing skills. Researchers also stress the importance of providing students at an early stage with specific strategies that can help them study the spelling of different vocabulary items.

\subsection{Spelling self-efficacy}

Self-efficacy is grounded in the theoretical framework of Bandura's social cognitive theory. According to Pajares (2002), Bandura introduced the construct of self-efficacy in his 1977 publication of "Self-efficacy: Toward a Unifying Theory of Behavioral Change" where he identified it as a missing and key element of social cognitive theory. In 1997, Bandura published "Self-Efficacy: The Exercise of Control", a book that delineated his theory of self-efficacy and he explained its applications to diverse fields such as life-course development, education, health, psychopathology, athletics, business, and international affairs. In other words, an individual's 
self-efficacy or belief in his or her capabilities to organize and execute the courses of action required to produce given attainments" is considered one of the most central psychological processes in Bandura's social cognitive theory (Bandura, 1997, p. 3).

Self-efficacy theory "posits that a belief in one's personal capabilities is central to how a person responds to tasks" (Maier \& Curtin, 2005, p.353). Efficacy beliefs are based on perceived capabilities and are domain and task specific (Zimmerman \& Cleary, 2006). A student may be confident in his ability to do well on a mathematics test but have low selfefficacy for reading aloud in language arts class. Across a variety of academic domains, self-efficacy has been shown to be a better predictor of achievement than past performance and intelligence (Bandura, 1997).

The process of creating self-efficacy is simple and rather intuitive. Individuals engage in behaviors, interpret the outcomes of their actions, use the interpretations to develop beliefs about their capabilities to engage in subsequent behaviors in the same domain, and behave in concert with the beliefs stated (Pajars, 1997, p.1). Pajares, Johnson, and Usher (2007) explain that self-efficacy beliefs are keys for human motivation, wellbeing, and sense of accomplishment because people have little incentive to get involved in difficult situations unless they believe that what they do will result in a desirable outcome. The greater a person's sense of selfefficacy, the more likely he or she is to address, restructure, and defuse stressful situations (Bandura, 1997).

The importance of self-efficacy beliefs lies in their potential influence over performance. Bandura (1997) and Pajares (1997) agree that people with high self-efficacy exert and sustain more effort, set challenging 
goals and maintain a strong commitment to them, approach difficult tasks as challenges to be mastered rather than as threats to be avoided. Furthermore, a strong self-efficacy produces higher levels of achievement within individuals. "Compared with learners who doubt their capabilities, those who feel self-efficacious about learning or performing a task competently are apt to participate more readily, work harder, persist longer when they encounter difficulties, and achieve at higher levels" (Schunk \& Meece, 2005, p. 71).

According to Bandura (1997), people are more likely to take on challenges for which they are self-efficacious, try harder to succeed at them, persist more in the face of obstacles and setbacks, and do so with less anxiety and negative affect. Bandura describes four sources of selfefficacy: (a) one's previous experiences with the task or domain, (b) the vicarious experiences one attains by observing others, (c) verbal persuasion, including encouragement and feedback, and (d) the physiological feedback one receives in association with the task, such as sweaty palms or a churning stomach. Zimmerman (2000) adds that the most influential source of self-efficacy beliefs is mastery experience followed by vicarious experiences, verbal persuasion and physiological state.

Perceived self-efficacy affects performance as individuals with similar skills may perform differently under the same circumstances depending on their beliefs of personal efficacy. According to Bandura (1997, p. 39), efficacy beliefs affect thought processes, level and persistence of motivation, and affective states. Self-efficacy beliefs are key factors for human motivation, well-being, and sense of accomplishment

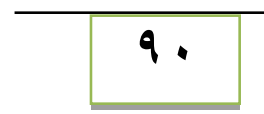


because there is little incentive to act or confront difficult situations unless people believe that what they do will result in a desirable outcome (Pajares, Johnson, \& Usher, 2007).

An examination into the literature revealed that a teacher can contribute to creating self-efficacy within students. Ormrod (2004, p. 125) offers a factor that could continue this cycle or break it down. When students are constantly faced with disappointment and failure, they are more likely to develop a lack of confidence. However, when students possess strong self-efficacy and then face an occasional setback, they learn perseverance because "they develop resilient self-efficacy." On the other hand, self-efficacy does not need to be very high for effective learning. The important issue is that the level of self-efficacy is high enough to sustain engagement in completing tasks in the present and future (Walker, 2003).

The construct of self-efficacy has a variety of characteristics that distinguish it from other self-perceptions, such as self-concept and selfesteem. For example, unlike self-concept, which involves a judgment of perceived competence (Eccles, Wigfield, \& Schiefele, 1998), self-efficacy involves perceptions of perceived confidence in successfully performing a given task at a certain level (Bandura, 1993). In addition, items that measure self-efficacy beliefs tend to direct respondents toward future behavior, whereas self-concept items are more past-oriented in that they direct respondents toward previous accomplishments (Bong \& Skaalvik, 2003).

Furthermore, Bandura (1997, p. 11) clarifies that self-efficacy "is concerned with judgments of personal capabilities, whereas self-esteem is concerned with judgments of self-worth." Specifically, a person may judge 
his/her inability to excel in a specific task negatively without thinking less of himself/herself. Eisenberger, Conti-D-Antonio, and Bertrando (2005, p. 208) state that "if you want to embrace mediocrity embrace self-esteem; if you want development embrace self- efficacy." In fact, students may judge themselves inefficacious in a task without suffering any loss of self-esteem because they do not invest their self-worth in the activity (Bandura, 1997).

Studies have shown that individuals with a higher self-efficacy achieve a greater academic success than those with lower self-efficacy scores (Urdan, 1997). A number of correlational studies pointed out that self-efficacy correlated positively with different language skills. For example, Shaw 's study (2007) indicated that reading and writing selfefficacy beliefs did indeed play a larger role in reading and writing performance for students with discrepant, rather than consistent, reading and writing performance. Similarly, Nevill (2008) revealed that reading self-efficacy is a predictor of both regulation of cognition and reading achievement in an intermediate elementary sample. In their study, Jones, Varberg, Manger, Eikeland, and Asbjørnsen (2012) also revealed that performance of reading and spelling tests (Reading Speed, Nonsense Words and Spelling) explained individual differences in the participants' efficacy beliefs in reading and writing.

In addition, self-efficacy beliefs can be developed using different programs and strategies like web based instruction (Cheng, 2003), concept mapping (Chularut \& DeBacker 2004), a unit based on Toulmin's model (El-Dib, Sadek, \& Zaza, 2004), multimedia ESP module (Lo, 2006), metacognitive reading course (McMurry, 2006), interactive process writing (Mostafa, 2002), oral reading fluency program (Olson, 2004), strategy 
instruction (Rossiter, 2002) and multiple intelligences (Shore, 2001). On the other hand, other studies used self-efficacy beliefs to develop different language skills like speaking (Amin, 2007), oral communication (Ali, 2010), and the four language skills (Templin, Guile, \& Okuma, 2001).

Concerning ADHD students, Major (2011) investigated the selfefficacy for learning beliefs of male and female youth with ADHD, and explored whether symptoms of inattention predict self-efficacy beliefs beyond internalizing symptoms and academic achievement. Results suggested that youth reporting high levels of inattention had lower perceptions of their ability to accomplish many academic tasks that require self-regulation.

To sum up, self-efficacy can affect students' academic performance as it creates greater interest in specific tasks and urges them to exert more sustained effort when obstacles get in the way of the task. So, the more students succeed in performing specific tasks, the better their sense of efficacy will be. In addition, the academic performance of students with learning disabilities like ADHD can be enhanced as a result of developing their self-efficacy in performing specific tasks and vice versa.

\subsection{Attention deficit hyperactivity disorder (ADHD)}

ADHD is a neurobiological disorder that starts during childhood and affects between 3 and $7 \%$ of school-aged children. It is characterised by a level of impulsivity, activity and attention that are not adequate for the development age. Many children and adolescents with ADHD find it difficult to regulate their behaviour and adjust to the rules expected for their age and, consequently, they find it difficult to adapt in their family and school environment, and in their relationships with their peers. They 
often perform below their capabilities and may present emotional and behavioural disorders (American Psychiatric Association, 2001). On the other hand, Barkley (1998) indicates that ADHD is a function of developmental failure in the brain circuitry that monitors inhibition and self-control. This loss of self-regulation impairs other important brain functions crucial for maintaining attention, including the ability to defer immediate rewards for later gain.

Researchers have estimated that between 2 and $18 \%$ of children currently exhibit behaviors associated with attention deficit hyperactivity disorder, commonly known as ADHD (Rowland, Lesesne, \& Abramowitz, 2002). Behaviors characteristic of ADHD are commonly identified during childhood, but the adverse symptoms often continue through adolescence and adulthood (National Institute of Mental Health, 2008). Although the disorder is typically diagnosed in childhood, it is estimated that 50 to $80 \%$ of cases persist into adolescence (Biederman, Petty, Evans, Smally, \& Farone, 2010; Resnick, 2005).

Individuals diagnosed with ADHD engage in behaviors often characterized as inattentive, hyperactive, or impulsive. Although these behaviors are not in themselves a learning disability, almost one-third of all children with ADHD have learning disabilities (National Institute of Mental Health [NIMH], 1999). In fact, because the symptoms associated with attentional disorders appear to be most apparent and problematic in educational settings, ADHD has even been defined as "a school-based disorder" (Atkins \& Pelham, 1991; p. 202). The school experience can be challenging for students with ADHD. Studies found that students with ADHD, compared to students without ADHD, had persistent academic 
difficulties that resulted in the following: lower average marks, more failed grades, more expulsions, increased dropout rates, and a lower rate of college undergraduate completion (Weiss \& Hechtman as cited in Johnston, 2002).

In classroom settings, ADHD students often complete work at rates lower than expected, produce work of poorer quality than they are capable of, and have difficulty maintaining on-task behaviors or following through when given instructions (Davies \& Witte, 2000). Because of their difficulties with inhibitory control, children with ADHD frequently fail to manage or control their behavioral responding (Shapiro, DuPaul, \& Bradley-Klug, 1998). Researchers have noted a need for interventions in the classroom that create additive effects beyond those established with medication to enhance educational outcomes for students with ADHD; important academic behaviors to target and assess include completion and accuracy of independent classwork and homework, as well as acquisition of skills taught in the curriculum (DuPaul \& Stoner, 2003).

Motivational deficits have been frequently observed in this population, as students with ADHD have been found to display less effort and persistence (Milich, 1994), a maladaptive response to failure (Barkley, 1997), abnormally high reward thresholds (Brim \& Whitaker, 2000), a performance goal orientation (Dunn \& Shapiro, 1999), and a greater preference for easy work compared to their normally developing peers (Carlson, Both, Shin, \& Canu, 2002). Furthermore, Volpe, DuPaul, DiPerna, Jitendra, Lutz, Tresco, and Junod (2006) found that low motivation in elementary students with ADHD was associated with poor study skills, which in turn, influenced achievement in reading and 
mathematics. These findings suggest that motivational deficits in ADHD may play an important role in the academic outcomes of these students.

Moreover, Shimabukuro, Prater, Jenkins, and Edelen-Smith (1999) investigated the effects of self-monitoring on the academic performance and on task behavior of three students with both learning disabilities and ADHD during independent class work in small group settings. All three students increased their academic productivity and accuracy, and their ontask behaviors improved across all academic areas. On the other hand, Harris, et al. (2005) examined the effects of self-monitoring of attention (SMA) and self-monitoring of performance (SMP) on the on-task and spelling behaviour of students with ADHD. Results indicated that the SMA and SMP procedures had a positive effect on the student's on-task behaviour and on their academic performance, as the SMA, for example, resulted in more correct practices for each student. In their study, Creel, Fore, Boon, and Bender also (2006) revealed that the use of the selfmonitoring procedures was effective for increasing classroom-preparedness skills for all four middle school students with ADHD.

Explicit development of self-regulation abilities may enhance the ontask and academic performance of ADHD students (DuPaul \& Stoner, 2002). In their study, Rafferty, Arroyo, Ginnane, and Wilczynski (2011) investigated the effects of self-monitoring on the on-task behavior and spelling accuracy of three fifth-grade students diagnosed with ADHD during an independent spelling practice period in the general education environment. Results showed that time on-task and spelling accuracy increased for the students diagnosed with ADHD during independent spelling practice after the teacher taught them how to self-monitor. These 
same students' on-task behavior also increased to levels comparable to that of their peers.

It is clear that ADHD learners represent a large population of students in our classes. In addition, they have specific characteristics that make it difficult for them to regulate their behaviour and academic performance in class. They can be classified depending on suitable diagnostic tests. They need much attention from their teachers to help them monitor their own progress. As a result, suitable strategies should be used to meet their needs.

\section{Methodology}

\subsection{Participants}

Participants of the study included 119 EFL fourth grade pupils at Mohamed Hassan Alzayat primary school in Damietta Governorate. They were randomly assigned into two groups, experimental (55 normal, 5 ADHD learners), and control (55 normal, 4 ADHD learners). Pupils' age in the two groups ranged from 9.8-10.4 years. These ADHD learners were identified using the diagnostic battery of children with ADHD prepared by Abd Alrahman Said Soliman and Mahmoud Mohamed El-Tantawe (2012).

\subsection{Design of the study}

The researcher used the progress-post test quasi-experimental design. The treatment was applied for five weeks, then the progress test was used to evaluate pupils' progress in spelling English words accurately. Then the treatment was carried out for another five weeks. The duration of the treatment was 10 weeks. The participants were divided into two groups. In the experimental group, the teacher used self-monitoring strategy to help pupils assess and record their progress in spelling English vocabulary. In 
the control group, vocabulary was taught in the traditional method. The design of the present study is summarized in figure (1).

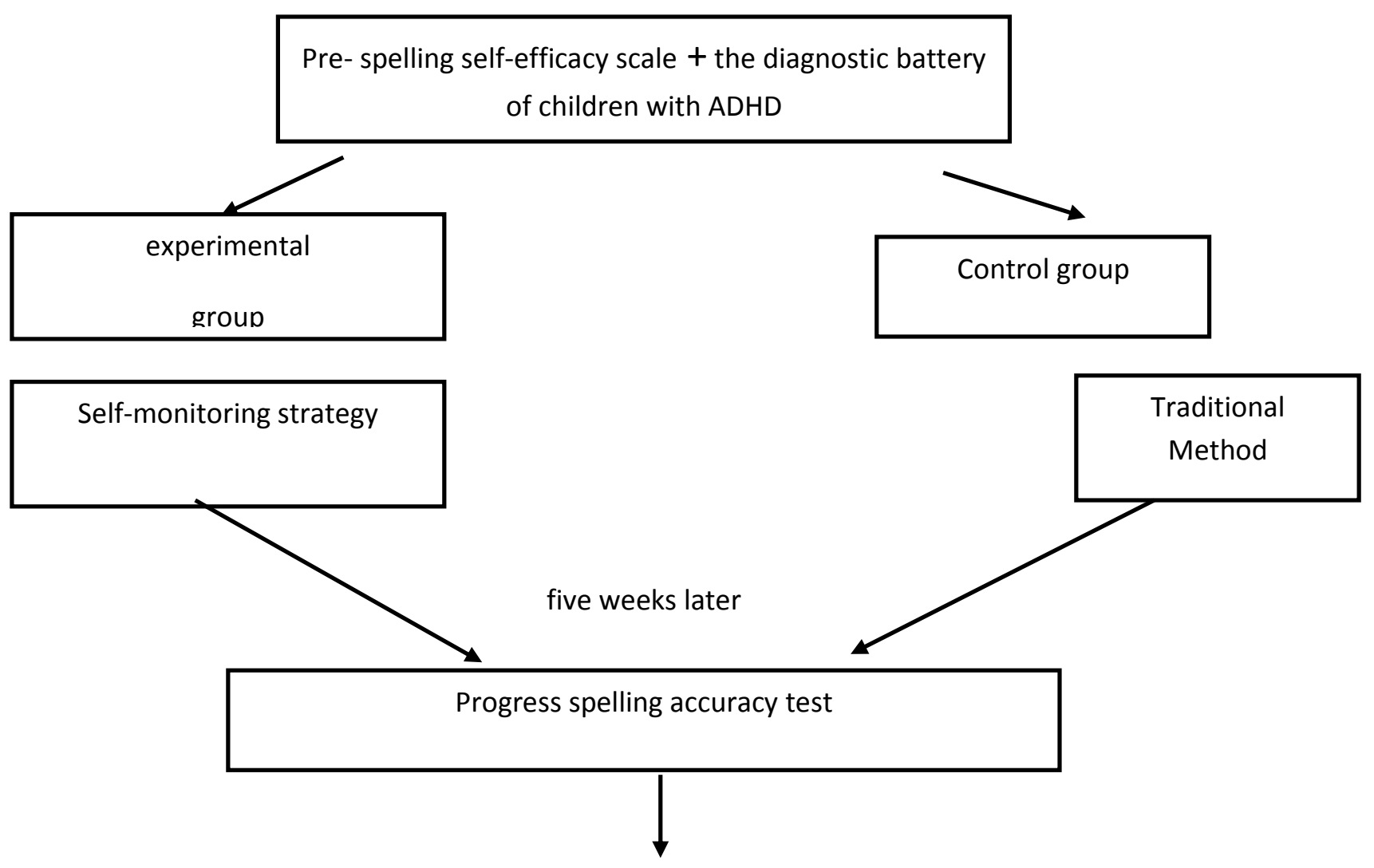

At the end of the treatment

Post spelling self-efficacy scale + post spelling accuracy test

Figure (1): Design of the present study 


\subsection{Instruments of the study}

Three instruments were used in this study: (available with the researcher upon request)

A- The diagnostic battery of children with ADHD prepared by Abd Alrahman Said Soliman and Mahmoud Mohamed El-Tantawe (2012).

B- The progress- post spelling accuracy tests.

C- The pre- post spelling self-efficacy scale.

A- The diagnostic battery of children with ADHD prepared by Abd Alrahman Said Soliman and Mahmoud Mohamed El-Tantawe (2012).

This diagnostic battery was mainly used to identify ADHD pupils in each group. The diagnostic battery is divided into two parts: the fist part is ADHD scale (family environment) and the second part is ADHD scale (school environment). For more details about the diagnostic battery, see Appendix A.

\section{B- The progress post spelling accuracy tests}

The tests were constructed in the light of the following resources:

- Reviewing previous studies concerned with language tests, especially those tackling the topic of how to develop spelling tests.

- The vocabulary items identified after reviewing Time for English 4, first term.

The purpose of these tests was to measure pupils' spelling accuracy of 60 English words. After reviewing Time for English 4, first term, 60 words were included in the progress- post spelling accuracy tests: 30 words in each test. It was given to two classes at the fourth grade. Each test included three questions. In the first question, pupils were required to listen and 
write ten words. The teacher first read the word then the sentence that included the word and finally read the word again (10 marks). As for the second question, pupils were asked to unscramble the letters of ten words and write them correctly. Finally, they were required in the third question to complete the missing letter in ten words. So, each spelling accuracy test was scored out of (30). The progress spelling accuracy test was administered to the two groups after five weeks of instruction immediately after session number 15 . The post spelling accuracy test was administered at the end of instruction after session 30. (For more details, see Appendix B).

In calculating the time needed for answering the tests, a group of 14 pupils answered the tests. The researcher recorded down the time each pupil finished answering each test. Then, time periods were averaged for the whole sample. The calculated mean time was 45 minutes for each session.

\section{Tests validity}

To measure tests content validity, the first version of the tests were given to EFL jury (N. 4) to evaluate each question in terms of types of questions, difficulty level, arrangement and number of questions. The tests proved to be valid as the jury approved all the questions. In addition, the calculated intrinsic validity for the progress and post spelling accuracy tests were 0.93 and 0.92 respectively. Therefore, the tests were considered valid for the purposes of the current study.

\section{Tests reliability}

In order to establish the reliability of the two tests, they were administered to a group of 50 EFL fourth grade pupils at Mohamed Hassan 
Alzayat primary school in Damietta Governorate. Those pupils were neither included in the control nor the experimental groups. The reliability coefficient was calculated using Cronback's Alpha (Marascuilo, 1971; Payne, 1997). The calculated reliability coefficient for the progress and post spelling accuracy tests were 0.86 and 0.859 respectively. Therefore, the tests were considered reliable for the purposes of the current study.

\section{D- The spelling self-efficacy scale}

The spelling self-efficacy scale was devised for assessing the effect of self- monitoring strategy on developing spelling self-efficacy of EFL fourth year primary school pupils with ADHA. The scale is based on Banadura's (1977) theory of self-efficacy and focuses on the different spelling tasks involved in class activities. This scale is a 10 item, selfreported measure, scored on a 3 point Likert scale (agree, undecided, or disagree) to measure pupil's beliefs about their spelling capabilities in performing specific English spelling tasks. So, the spelling self-efficacy scale was scored out of (30). The scale is written in Arabic. For more details about the scale, see Appendix (C).

\section{Validity and reliability}

Before using the scale, it was presented to a panel of jury of specialists in educational psychology and TEFL (N. 5). Their opinions concerning categories and domains of analysis were taken into consideration. Based on their suggestions, all the statements in the scale were positive ones since it is easier for both the researcher to score the statements and the pupils to express their points of view. These opinions were taken into consideration when preparing the final version of the scale. In addition, two statements were excluded since they were repeated in other 
statements. Moreover, the calculated intrinsic validity for the spelling selfefficacy scale was 0.83 . Therefore, the scale was considered valid for the purposes of the current study.

The scale was administered to 59 EFL fourth grade pupils at Mohamed Hassan Alzayat primary school in Damietta Governorate (not included in the main treatment). Cronback's Alpha (Marascuilo, 1971; Payne, 1997) was used to calculate the reliability coefficient of the scale. The calculated reliability coefficient was 0.70 . Thus, the scale is reliable to be used in assessing EFL fourth grade pupils' spelling self-efficacy.

\subsection{The treatment}

* Aim of the treatment

This treatment aimed at helping EFL fourth grade pupils with ADHD to spell English vocabulary accurately and at the same time improve their spelling self-efficacy.

* Objectives of the treatment

By the end of this treatment, pupils were expected to use selfmonitoring strategy to:

- spell the selected vocabulary items correctly.

- unscramble and write the selected vocabulary items correctly.

- complete the missing letter in the selected vocabulary items correctly.

* Content and duration of the treatment

The content was divided into two parts, each part included the words included in three units. These words were taught in 30 sessions over a period of ten weeks of instruction. Prior to the treatment, the teacher taught a five-step spelling study strategy to all students in the experimental group during an orientation session. She told all participants in the study to use 
this strategy during the independent spelling study sessions. The teacher assessed each pupils to make sure he/she was able to implement the strategy with fidelity. The steps of a spelling study strategy used by Harris et al. (2005) was modified and used in this study. The steps were as follows: "(a) look at the word, (b) spell the word aloud, (c) cover the word, (d) write the word three times, and (e) check to see if the word is spelled correctly" (Harris et al., p. 149). The teacher listed the study strategy steps on the wall chart. This wall chart was visible to all pupils in the classroom, and it was visible every day that the pupils practiced their spelling words. Coloured copies of this spelling strategy (LSCWC) was given to all pupils in the experimental group at the beginning of the treatment to help them practice during independent spelling study sessions and at home. (For more details, see appendix D).

During the last 10 minutes of the 45 minutes instructional period, the pupils spent time studying their weekly spelling words. Each student received 10 spelling words list a week. Throughout the experiment, pupils used the steps of LSCWC for all of their words, and if time allowed, they started again with the first word. Any paper(s) used to complete spelling practices were placed in the student's spelling file at the end of the 10minute study period. Moreover, each pupil used two self- monitoring cards; one for the weekly spelling tests and the other one is used for the spelling study sessions. In both cards, each pupil had to colour the stars that represented the number of words accurately spelled either in the weekly spelling tests or at the end of the session. (For more details, see appendix E). 
The treatment was administered in the first term of the school year 2013/2014. The procedures followed in each session for the experimental group were as the following:

1- T. reminded the pupils of the steps of the LSCWC strategy.

2- Pupils used the spelling strategy to study the 10 words included in the weekly list.

3- Pupils used their self- monitoring card to record their progress and count the number of words spelled correctly.

4- Pupils coloured the stars that represented the number of words spelled correctly.

5- Pupils took copies of their spelling home assignment that include two main exercises; unscramble and write and complete the missing letter.

6- T. provided model answer of the home assignment at the beginning of the following session.

7- Pupils used peer evaluation to score their home assignment.

* Evaluation

The evaluation techniques used in the program consisted of both quantitative and qualitative evaluation. Quantitative evaluation was divided into formative and summative evaluation:

•Formative evaluation

It was used for the purpose of assessing the progress of the pupils in spelling accuracy as well as providing the necessary feedback that can help them use self- monitoring strategy appropriately to spell vocabulary items accurately. Pupils used to have a weekly spelling test at the end of the third session. They were encouraged to use a breathing technique before these 
test to help them control their anxiety. They also had home assignments related to two spelling questions: unscramble and write and complete the missing letter at the end of each session.

- Summative evaluation

It included the administration of the progress-post spelling accuracy tests and pre-post spelling self-efficacy to investigate the effectiveness of the treatment in developing English spelling accuracy and self- efficacy of the two groups.

Concerning qualitative evaluation, in every session the teacher used to collect some of the pupils' self- monitoring cards to encourage them. The teacher also kept written records for ADHD pupils. These records included the date and the comments of the teacher on pupils' performance concerning their self-monitoring cards and home assignment. Qualitative data that shows the progress of each of the five ADHD pupils in the experimental group is summarized in appendix F. For more details about the treatment, see appendix G.

\section{Results and discussion}

\subsection{Results}

The results of the study will be presented in terms of the study hypotheses as follows:

Hypothesis one: There would be statistically significant differences between the mean scores of the experimental group and the control group on the progress spelling accuracy test in favour of the former.

In order to test the previous hypothesis, the researcher used MannWhitney test for ADHD pupils and independent samples T-test for normal 
pupils. The results of these tests proved to be consistent with the above stated hypothesis. The following table shows this statistical significance.

Table (1)

Mann-Whitney test of the progress spelling accuracy test of ADHD

\begin{tabular}{|l|l|l|l|l|l|c|}
\hline & \multicolumn{1}{|c|}{ Group } & N & Mean Rank & $\begin{array}{c}\text { Sum of } \\
\text { Ranks }\end{array}$ & Z-test & Sig. \\
\hline $\begin{array}{l}\text { ADHD } \\
\text { pupils }\end{array}$ & Control & 4 & 2.75 & 11.0 & 2.21 & 0.027 \\
\cline { 2 - 7 } & Experimental & 5 & 6.80 & 34.0 & 2.0 & \\
\hline
\end{tabular}

Table (2)

Independent samples T-test of the progress spelling accuracy test of normal pupils

\begin{tabular}{|l|l|r|l|c|c|c|}
\hline & \multicolumn{1}{|c|}{ Group } & $\mathrm{N}$ & \multicolumn{1}{c|}{ Mean } & SD & T-test & Sig. \\
\hline $\begin{array}{l}\text { Normal } \\
\text { pupils }\end{array}$ & Control & 55 & 15.08 & 3.58 & 2.91 & 0.004 \\
\cline { 2 - 7 } & Experimental & 55 & 16.88 & 3.15 & & \\
\hline
\end{tabular}

It is apparent from data presented in table (1) and table (2) that there were statistically significant differences between the control and experimental groups on the progress spelling accuracy test in favour of the latter for both ADHD and normal pupils. Thus the first hypothesis was accepted.

Hypothesis two: There would be statistically significant differences between the mean scores of the experimental group and the control group on the post spelling accuracy test in favour of the former.

The aforementioned hypothesis has been verified in the present study. Tables (4) and (5) show the variance of the two groups on the post spelling accuracy test. 
Table (3)

Mann-Whitney test of the post spelling accuracy test of ADHD in the two

\begin{tabular}{|l|l|l|l|l|l|c|}
\multicolumn{2}{c|}{ groups } \\
\hline & \multicolumn{1}{|c|}{ Group } & $\mathrm{N}$ & Mean Rank & $\begin{array}{c}\text { Sum of } \\
\text { Ranks }\end{array}$ & Z-test & Sig. \\
\hline $\begin{array}{l}\text { ADHD } \\
\text { pupils }\end{array}$ & Control & 4 & 2.50 & 10.0 & 2.46 & 0.001 \\
\cline { 2 - 8 } & Experimental & 5 & 7.00 & 35.0 & & 0.0 \\
\hline
\end{tabular}

Table (4)

Independent samples T-test of the post spelling accuracy test of normal pupils

\begin{tabular}{|l|l|c|l|c|c|c|}
\hline & \multicolumn{1}{|c|}{ Group } & $\mathrm{N}$ & \multicolumn{1}{|c|}{ Mean } & SD & T-test & Sig. \\
\hline \multirow{2}{*}{$\begin{array}{l}\text { Normal } \\
\text { pupils }\end{array}$} & Control & 55 & 15.20 & 3.63 & \multirow{2}{*}{11.22} & 0.001 \\
\cline { 2 - 7 } & Experimental & 55 & 22.27 & 3.23 & & \\
\hline
\end{tabular}

Close inspection of data presented in table (3) and table (4) reveals that there were statistically significant differences at 0.001 level in the variance of ADHD and normal pupils in the two groups in favour of the experimental group. Therefore, this provides enough evidence to support hypothesis two.

Hypothesis three: There would be statistically significant differences between the mean scores of the progress spelling accuracy test and post spelling accuracy test for the experimental group in favour of the latter.

In order to test the previous hypothesis, the researcher used Wilcoxon Signed Ranks test for ADHD pupils and Paired samples T-test for normal pupils. The results of these tests proved to be consistent with the above stated hypothesis. The following table shows this statistical significance. 
Table (5)

Wilcoxon Signed Ranks test of the progress- post spelling accuracy test of normal pupils in the experimental group

\begin{tabular}{|l|l|l|l|l|l|l|}
\hline Groups & Test & N & $\begin{array}{l}\text { Mean } \\
\text { Rank }\end{array}$ & $\begin{array}{l}\text { Sum of } \\
\text { Ranks }\end{array}$ & Z-test & $\begin{array}{l}\text { P- } \\
\text { value }\end{array}$ \\
\hline \multirow{2}{*}{$\begin{array}{l}\text { Experimental } \\
\text { group } \\
\text { (Post- }\end{array}$} & Negative & 0 & 0.0 & 0.0 & \multirow{2}{*}{2.0} & 0.042 \\
\cline { 2 - 7 } Progress) & Positive Ranks & 5 & 3.0 & 15.0 & 2.0 & \\
\cline { 2 - 7 } & Ties & 0 & & & & \\
\cline { 2 - 5 } & Total & 5 & & & & \\
\hline
\end{tabular}

Table (6)

Paired samples T-test of the progress- post spelling accuracy test of normal pupils in the experimental group

\begin{tabular}{|l|l|l|l|l|l|l|}
\hline Groups & Test & $\mathrm{N}$ & Mean & SD & T-test & P-value \\
\hline \multirow{2}{*}{$\begin{array}{l}\text { Experimental } \\
\text { group }\end{array}$} & Progress-test & 55 & 16.88 & 3.15 & \multirow{2}{*}{11.12} & 0.001 \\
\cline { 2 - 7 } & Post-test & 55 & 22.27 & 3.23 & & \\
\hline
\end{tabular}

It is apparent from data presented in table (5) and table (6) that for the experimental group, there were statistically significant differences at 0.001 level between the mean scores of the progress spelling accuracy test and post spelling accuracy test in favour of the latter for both ADHD and normal pupils. Thus, the third hypothesis was accepted.

Hypothesis four: There would be statistically significant differences between the mean scores of the experimental group and the control group on the post self-efficacy scale in favour of the former. 
Table (7)

Mann-Whitney test of the post self-efficacy scale of ADHD

\begin{tabular}{|l|l|l|l|l|l|l|}
\hline & \multicolumn{1}{|c|}{ Group } & N & Mean Rank & $\begin{array}{c}\text { Sum of } \\
\text { Ranks }\end{array}$ & Z-test & Sig. \\
\hline $\begin{array}{l}\text { ADHD } \\
\text { pupils }\end{array}$ & Control & 4 & 2.50 & 10.0 & 2.46 & 0.001 \\
\cline { 2 - 7 } & Experimental & 5 & 7.00 & 35.0 & & \\
\hline
\end{tabular}

Table (8)

Independent samples T-test of the post self-efficacy scale of normal pupils

\begin{tabular}{|l|l|c|l|c|c|c|}
\hline & \multicolumn{1}{|c|}{ Group } & $\mathrm{N}$ & \multicolumn{1}{|c|}{ Mean } & SD & T-test & Sig. \\
\hline \multirow{2}{*}{$\begin{array}{l}\text { Normal } \\
\text { pupils }\end{array}$} & Control & 55 & 14.46 & 3.71 & \multirow{2}{*}{7.98} & 0.001 \\
\cline { 2 - 7 } & Experimental & 55 & 19.78 & 3.57 & & \\
\hline
\end{tabular}

In order to verify the validity of this hypothesis, Mann-Whitney test

for ADHD pupils and independent samples T-test for normal pupils were used. The results presented in the previous two tables proved that there were statistically significant differences at 0.001 level in the variance of ADHD and normal pupils in the two groups in favour of the experimental group. Therefore, this provides enough evidence to support hypothesis four.

Hypothesis five: There would be statistically significant differences between the mean scores of the pre self-efficacy scale and post selfefficacy scale for the experimental group in favour of the latter.

In order to test the previous hypothesis, the researcher used Wilcoxon Signed Ranks test for ADHD pupils and Paired samples T-test for normal pupils. The results of these tests proved to be consistent with the above stated hypothesis. The following two tables show this statistical significance. 
Table (9)

Wilcoxon Signed Ranks test of the pre- post self-efficacy scale of normal pupils in the experimental group

\begin{tabular}{|l|l|l|l|l|l|l|}
\hline Groups & Test & N & $\begin{array}{l}\text { Mean } \\
\text { Rank }\end{array}$ & $\begin{array}{l}\text { Sum of } \\
\text { Ranks }\end{array}$ & Z-test & $\begin{array}{l}\text { P- } \\
\text { value }\end{array}$ \\
\hline \multirow{2}{*}{$\begin{array}{l}\text { Experimental } \\
\text { group } \\
\text { (Post-Pre) }\end{array}$} & Negative & 0 & 0.0 & 0.0 & \multirow{2}{*}{2.0} & \multirow{2}{*}{0.042} \\
\cline { 2 - 5 } & Positive Ranks & 5 & 3.0 & 15.0 & & \\
\cline { 2 - 7 } & Ties & 0 & & & & \\
\cline { 2 - 6 } & Total & 4 & & & & \\
\hline \multicolumn{7}{|c|}{ Table (10) }
\end{tabular}

Paired samples T-test of the pre- post self-efficacy scale of normal pupils in the experimental group

\begin{tabular}{|l|l|l|l|l|l|c|}
\hline Groups & Scale & $\mathrm{N}$ & Mean & SD & T-test & P-value \\
\hline \multirow{2}{*}{$\begin{array}{l}\text { Experimental } \\
\text { group }\end{array}$} & Pre-scale & 55 & 16.88 & 3.15 & \multirow{2}{*}{11.12} & 0.001 \\
\cline { 2 - 5 } & Post-scale & 55 & 22.27 & 3.23 & & \\
\hline
\end{tabular}

Based on tables (9) and (10), it could be stated that there were statistically significant differences between the mean scores of the pre selfefficacy scale and post self-efficacy scale for both ADHD and normal pupils for the experimental group in favour of the latter. Therefore, there is enough evidence to support hypothesis five.

In addition, to calculate the effect size of the self- monitoring strategy on the spelling accuracy and self-efficacy of the experimental group, the researcher used Eta square.

Table (11)

Effect size of the self-monitoring strategy on spelling accuracy

\begin{tabular}{|l|l|l|l|l|}
\hline Test & Mean & T-test & Eta square & $\mathrm{D}$ \\
\hline Progress-test & 16.88 & \multirow{2}{*}{11.12} & 0.68 & 2.89 \\
\hline Post-test & 22.27 & & & \\
\hline
\end{tabular}


Table (12)

Effect size of the self-monitoring strategy on spelling self-efficacy

\begin{tabular}{|l|l|l|l|l|}
\hline Scale & Mean & T-test & Eta square & D \\
\hline Pre-scale & 14.42 & 7.84 & 0.51 & 2.04 \\
\hline Post-scale & 19.78 & & & \\
\hline
\end{tabular}

The results obtained in table (11) and (12) reveal that the effect size of the self- monitoring strategy on English spelling accuracy and self-efficacy is large since $\mathrm{D}$ value is more than 0.8 .

\subsection{Discussion}

The first result showed that there were statistically significant differences at there were statistically significant differences between the control and experimental groups on the progress and post spelling accuracy tests in favour of the latter for both ADHD and normal pupils. This positive result supports the findings of other studies like those of Gureasko-Moore et al., (2007), Harris et al., (2005) and Rock and Thead (2007). This progress might be attributed to the following factors:

- Giving ADHD learners the chance to use specific spelling study strategy LSCWC provided the motivation and individual attention that ADHD learners needed to improve their spelling accuracy.

- Using self-monitoring cards gave ADHD learners the chance to practice self-monitoring strategy to observe and record their progress in spelling accuracy.

- Colouring the stars in the self-monitoring cards was fun and motivating to pupils. 
- Observing others while using the spelling strategy motivated ADHD pupils to regulate their behavior and pay more attention to their spelling tasks.

In addition, the second result revealed that for the experimental group, there were statistically significant differences at 0.001 level between the mean scores of the progress spelling accuracy test and post spelling accuracy test in favour of the latter for both ADHD and normal pupils. But there were no such difference for pupils in the control group. This result might be due to the fact that the more time pupils spend in practicing selfmonitoring strategy, the better their spelling accuracy will be.

The third result showed that there were statistically significant differences at 0.001 level in the variance of the scores of the post spelling self- efficacy scale of ADHD and normal pupils in the two groups in favour of the experimental group. This positive result supports the findings of other studies like those of Major (2011). This progress might be attributed to the following factors:

- The most influential sources of self-efficacy were taken into consideration when applying the self- monitoring strategy. When pupils experienced success in spelling, their spelling self-efficacy improved. Observing others while using LSCWC and self- monitoring cards helped them attain vicarious experiences. Moreover, providing pupils with encouragement and immediate feedback by using self-monitoring card improved their motivation to succeed. Finally, encouraging pupils to use a breathing technique before spelling tests helped them control their anxiety before these tests. 
- The more ADHD pupils practised self- monitoring strategy, the better they were in English spelling accuracy that was a source of improving their spelling self- efficacy.

\section{Conclusions, recommendations and suggestions for further research}

\subsection{Conclusions}

It is important to mention that the results of the study are limited by the sample size, the characteristics of the subjects, the length of the study and the selected vocabulary items used in the study. Within these limitations, it can be concluded that the self- monitoring strategy is effective in developing English spelling accuracy and self-efficacy of EFL primary school pupils with ADHD. In addition, when pupils with ADHD experience success in spelling English words, their self-efficacy improve since the sources of self-efficacy are impeded in self- monitoring strategy. These results support the indicators of success the self-monitoring studies revealed in other contexts (Gureasko-Moore et al., 2007; Harris et al., 2005; Rafferty et al., 2011; Rock \& Thead, 2007). To sum up, the results of the study can provide the basis for many other treatments based on selfmonitoring strategy to develop different skills in different language learning contexts.

\subsection{Recommendations}

Based on the results of this study and the above mentioned conclusions, the following recommendations seem pertinent:

1-EFL teachers should be encouraged to use self- monitoring strategy to teach pupils how to spell accurately for the following reasons: 
- It helps pupils, especially those with ADHD, to use different senses to spell different vocabulary items.

- It helps them use specific steps to study spelling of English words like LSCWC spelling strategy.

- It is flexible as pupils can practice it as individuals or groups or as a whole class.

- It is fun and motivating as students can show their progress through colouring the stars in their self-monitoring cards.

- It has the potential to provide ongoing, frequent, and immediate feedback that is highly contiguous with the target behaviours.

2- ADHD learners should be given special interventions to compensate for their inability to regulate their behaviour and academic performance in class.

3- Educators should strongly consider teaching their students how to selfmonitor to help them make academic gains and be socially accepted in the classroom.

\subsection{Suggestions for further research}

1- Conducting studies to use self-monitoring strategy with EFL learners at various educational levels and in different language learning contexts.

2- More research is needed to examine the effectiveness of self-monitoring strategy in developing different language skills.

3- More research is needed to examine different strategies that help ADHD learners to spell English vocabulary items.

4- Conducting studies to examine different strategies that could help ADHD learners improve their self-efficacy. 


\section{References}

Abu Ghazalah, I. (2010). The effect of using a comprehensive approach for teaching high frequency words on developing the writing skill of seventh graders in Gaza. Published masters' thesis. The Islamic University of Gaza. Retrieved July 16, 2013, from http://library.iugaza.edu.ps/ thesis / 90211.pdf

Agran, M., Sinclair, T., Alper, S., Cavin, M., Wehmeyer, M. \& Hughes, C. (2005). Using self-monitoring to increase following direction skills of students with moderate to severe disabilities in general education. Education and Training in Developmental Disabilities, 40, 3-13.

Alber, S. \& Walshe, S. (2004). When to self-correct spelling words: A systematic replication. Journal of Behavioral Education, 13(1), 5166.

Ali, H. (2010). The effectiveness of a self-efficacy based program in developing EFL oral communication skills among prospective teachers. Unpublished masters' thesis, Faculty of Education. Benha University.

Al-Jarf, R. (2008). Sources of Spelling Errors in EFL Arab College Students. Retrieved March 17, 2013, from faculty.ksu.edu.sa Amato-Zech, N., Hoff, K., \& Doepke, K. (2006). Increasing on-task behavior in the classroom: Extension of self-monitoring strategies. Psychology in the Schools, 43(2), 211-221.

American Psychiatric Association (2000). Diagnostic and Statistical Manual of Mental Disorders. Washington, D.C.: American Psychiatric Association. 
Amin, E. (2007). A suggested self-efficacy-based program for developing secondary school students' EFL speaking skills. Unpublished masters' thesis, Faculty of Education. Benha University.

Awad, A.(2010). The impact of English orthography on Arab EFL learners' pronunciation of English. Published masters' thesis. Hebron University, Palestine. Retrieved April 26, 2013, from dspace.ju.edu.jo/xmlui/handle/

Bandura, A. (1993). Perceived self-efficacy in cognitive development and functioning. Educational Psychologist, 28(2), p. 117-148. Retrieved September 14, 2013, from ProQuest database.

Bandura, A. (1994). Self-efficacy. In V. S. Ramachaudran (Ed.), Encyclopedia of human behavior (pp. 371-381). New York: Academic Press.

Bandura, A. (1997). Self-efficacy: The exercise of control. New York: Freeman.

Barkley, R. A. (1997). Behavioral inhibition, sustained attention and executive functions: Constructing a unifying theory of ADHD. Psychological Bulletin, 121, 65-94.

Barkley, R. A. (1998). Attention-deficit hyperactivity disorder. Scientific American, 279, 3.

Biederman, J., Petty, C., Evans, M., Small, J., \& Faraone, S. (2010). How persistent is ADHD? A controlled 10-year follow-up study of boys with ADHD. Psychiatry Research, 177, 299-304.

Berninger, V., Abbott, R., \& Abbott, S. (2002). Writing and reading: Connections between language by hand and language by eye. Journal of Learning Disabilities, 35, 39-56. 
Bong, M., \& Skaalvik, E. (2003). Academic self-concept and self-efficacy: How different are they really? Educational Psychology Review, 15(1), 1-39.

Brim, S., \& Whitaker, D. (2000). Motivation and students with attention deficit hyperactivity disorder. Preventing School Failure, 44, 57-60.

Brooks, A., Todd, A., Tofflemoyer, S., \& Horner, R. (2003). Use of functional assessment and a self-management system to increase academic engagement and work completion. Journal of Positive Behavior Interventions, 5(3), 144-152.

Burt, J., \& Tate, H. (2002). Does a reading lexicon provide orthographic representations for spelling? Journal of Memory and Language, 46, 518-543.Caravolas, M., Hulme, C., Snowling, M. (2001). The foundations of spelling ability: Evidence from a 3-year longitudinal study. Journal of Memory and Language, 45, 751-774.

Carlson, C., Both, J., Shin, M., \& Canu, W. (2002). Parent-, teacher-, and self-rated motivational styles in ADHD subtypes. Journal of Learning Disabilities, 35, 104-113.

Cheng, Y. (2003). The effects of web based instruction on Chinese EFL students learning outcomes. DAI-A, 64(2), 382.

Chularut, P., \& DeBacker, T. (2004). The influence of concept mapping on achievement, self-regulation, and self-efficacy in students of English as a second language. Contemporary Educational Psychology, 29, 248-263.

Cooper, J. O., Heron, T. E., \& Heward, W. L. (2007). Applied behavior analysis. Columbus, OH: Pearson/Merrill/Prentice Hall. 
Crawley, S. H., Lynch, P., \& Vannest, K. (2006). The use of selfmonitoring to reduce off-task behavior and cross-correlation examination of weekends and absences as an antecedent to off-task behavior. Child \& Family Behavior Therapy, 28(2), 29-48.

Creel, C., Fore, C., Boon, R., \& Bender, W. (2006). Effects of selfmonitoring on classroom preparedness skills of middle school students with attention deficit hyperactivity disorder. Learning Disabilities: A Multidisciplinary Journal, 14(2), 105-114.

Davies, S., \& Witte, R. (2000). Self-management and peer monitoring within a group contingency to decrease uncontrolled verbalizations of children with attention-deficit/ hyperactivity disorder. Psychology in Schools, 37, 135-147.

Dedham, S., \& Mohammed, W. (2008). Iraqi EFL learners' performance in English spelling. Published masters' thesis, College of Education. University of Babylon. Retrieved July 14, 2013, from www.uobabylon.edu.iq/uobcoleges/

Dunn, P.B., \& Shapiro, S.K. (1999). Sex differences in the achievement goal orientations of ADHD children. Cognitive Therapy and Research, 23, 327-344.

DuPaul, G. J., \& Stoner, G. (2003). ADHD in the schools: Assessment and intervention strategies. New York: Guilford Press.

Eccles, J. S., Wigfield, A., \& Schiefele, U. (1998). Motivation to succeed. In W. Damon, \& N. Eisenberg (Eds.), Handbook of child psychology, 5th ed.: Vol 3. social, emotional, and personality development (pp. 1017-1095). Hoboken, NJ, US: John Wiley \& Sons Inc. 
Ehri, L.C. (1997). Learning to read and learning to spell are one and the same thing, almost. In C.A. Perfetti, L. Rieben, \& M. Fayol (Eds.), Learning to spell - Research, theory and practice across languages (pp. 237-269). Mahwah, NJ: Lawrence Erlbaum Associates.

Ehri, L. (2005). Learning to read words: Theory, findings, and issues. Scientific Studies of Reading, 9, 167-188.

Ehri, L., \& Snowling, M. (2004). Developmental variation in word recognition. In C. Stone, E. Silliman, B. Ehren, \& K. Apel (Eds.), Handbook of language and literacy (pp. 433-460). New York: Guilford Press.

Eisenberger, J., Conti-D-Antonio, M., \& Bertrando, R. (2005). Selfefficacy: Raising the bar for all students. Larchmont, NY: Eye on Education.

El-Dib, M., Sadek, F., \& Zaza, M. (2004).The effects of an instructional unit based on Toulmin' s model of argumentation on college students' writing performance, writing efficacy and writing apprehension. Journal of Psychological and Educational Research, 19(2), 1-42.

Fender, M. (2008). Spelling knowledge and reading development: Insights from Arab ESL Learners. Reading in a Foreign Language, 20(1), 1942.

Freeman, D. \& Freeman, Y. (2004). Essential linguistics: What you need to know to teach reading, ESL, spelling, phonics, and grammar. Plymouth, NH: Heinemann.

Ganske, K. (1999). The Developmental Spelling Analysis: A measure of orthographic knowledge. Educational Assessment, 6(1), 41-70. 
Ganz, J. (2008). Self-monitoring across age and ability levels: Teaching students to implement their own positive behavioral interventions. Preventing School Failure, 53(1), 39-48.

Ganz, J. B., \& Sigafoos, J. (2005). Self-monitoring: Are young adults with MR and autism able to utilize cognitive strategies independently? Education and Training in Developmental Disabilities, 40(1), 24-33.

Gentry, J. R. (1997). My kid can't spell. Portsmouth, NH: Heinemann.

Graham, S. (1999). Handwriting and spelling instruction for students with learning disabilities: A review. Learning Disability Quarterly, 22, 78-98.

Gulchak, D. (2008). Using a mobile handheld computer to teach a student with an emotional and behavioral disorder to self-monitor attention. Education and Treatment of Children, 31(4), 567-581.

Gureasko-Moore, S., Dupaul, G., \& White, G. (2006). The effects of selfmanagement in general education classrooms on the organizational skills of adolescents with a label of ADHD. Behavior Modification, 30, 159-183.

Harris, K., Graham, S., Reid, R., McElroy, K., \& Hamby, R. (1994). Selfmonitoring of attention versus self-monitoring of performance: Replication and cross-task comparison. Learning Disability Quarterly, 17, 121-139.

Harris, K., Friedlander, B., Saddler, B., Frizzelle, R., \& Graham, S. (2005). Self-monitoring of attention versus self-monitoring of academic performance: Effects among students with ADHD in the general education classroom. Journal of Special Education, 39(3), 145-156. 
Hasan, J. (2000). Assessment of pupils' errors in English spelling. Published masters' thesis, College of Education / Ibn- Rushid. Baghdad University. Retrieved June 14, 2013, from www.uobabylon.edu.iq/uobcoleges/ fileshare/articles/2.

Hoff, K., \& DuPaul, G. (1998). Reducing disruptive behavior in general education classrooms: The use of self-management strategies. School Psychology Review, 27, 290-303.

Hughes, C., Copeland, S., Agran, M., Wehmeyer, M., Rodi, M., \& Presley, J. (2002). Using self-monitoring to improve performance in general education high school classes. Education and Training in Mental Retardation and Developmental Disabilities, 37, 262-272.

Jones, S., Varberg, J ., Manger T., Eikeland, O., \& Asbjørnsen, A. (2012). Reading and writing self-efficacy of incarcerated adults. Learning and Individual Differences. 22, 343-349.

Johnston, C. (2002). The impact of attention deficit hyperactivity disorder on social and vocational functioning in adults. In P.S. Jensen and J.R. Cooper (Eds.), Attention deficit hyperactivity disorder: State of the science, best practices (pp. 1-21). Kingston, NJ: Civic Research Institute.

Kharma, N., \& Hajjaj, A. (1989). Errors in English among Arabic speakers: Analysis and remedy. Harlow, UK: Longman.

Klassen, R., \& Usher, E. (2010). Self-efficacy in educational settings: Recent research and emerging directions. In T. Urdan \& S. Karabenick (Eds.), Advances in motivation and achievement, the decade ahead: Theoretical perspectives on motivation and achievement (pp. 1-33). Bingley: Emerald Books. 
Koegel, L., Koegel, R., Harrower, J., \& Carter, C. (1999). Pivotal response intervention 1: Overview of approach. The Journal of the Association for Persons with Severe Handicaps, 24, 175-185.

Larson, S., Hammill, D., \& Moats, L. (1999). Test for written spelling: Examiner's manual. Austin, Texas: Pro-ed.

Levendoski, L., \& Cartledge, G. (2000). Self-monitoring for elementary school children with serious emotional disturbances: Classroom applications for increased academic responding. Behavioral Disorders, 25(3), 211-224.

Lo, C. (2006).The effects of a multimedia ESP instructional module on students learning performance and perceived self-efficacy. ADI-A, 67(2), 446.

Loftin, R., Gibb, A., \& Skiba, R. (2005). Using self-monitoring strategies to address behavior and academic issues. Impact, 18(2), 12-13.

Major, A. (2011). Understanding the self-Efficacy for learning beliefs of adolescents with ADHD. Published masters' thesis, Ontario Institute of Studies in Education. University of Toronto. Retrieved July 14, 2013, from https:/ /tspace. library. utoronto. ca/bitstream/ 1807/29479/1/ Major_Ashley_C_201103_MA_thesis.

Maier, S., \& Curtin, P. (2005). Self-efficacy theory: A perspective model for teaching research methods. Journalism \& Mass Communicator Educator, 59(4). 1- 13. Retrieved October 18, 2007, from ProQuest database.

Marascuilo, L. (1971). Statistical methods for behavioral science research. USA: McGraw-Hill Book Company. 
McMurry, E. (2006). The impact of a metacognitive college reading course on students' comprehension, reading self-efficacy, and subsequent English course grades. Published doctoral dissertation, Brigham Young University. Retrieved June 14, 2013, from wwwlib.umi.com/dissertation

Meriem, B. (2010). Teaching and Learning Vocabulary through Spelling Strategy: A Case Study of First-Year LMD Students. Published masters' thesis, Mentouri University, Constantine Algeria. Retrieved June 24, 2013, from bu.umc.edu.dz/theses/anglais/BOU1177.pdf

Mesmeh, T. (2012). The effect of the cover, copy and compare strategy on the ninth graders' acquisition and retention of spelling and their attitudes towards the strategy. Published masters' thesis, The Islamic University of Gaza. Retrieved April 13, 2013, from library. iugaza. edu.ps /thesis/ 101557.pdf

Milich, R. (1994). The response of children with ADHD to failure: If at first you don't succeed, do you try, try, again? School Psychology Review, 23, 11-28.

Mitchum, K., Young, K. , West, R. , \& Benyo, J. (2001). CSPASM: A class wide peer assisted self-management program for general education classrooms. Education and Treatment of Children, 24, 111-140.

Moats, L. (2010). What does spelling have to do with reading comprehension? Idaho RTI Conference. Retrieved July 22, 2013, from http:// www. docin. com/p-425608685.html

Mostafa, A. (2002). The effectiveness of a proposed interaction process model in the writing performance, self-efficacy and apprehension of 
ESP college students. Journal of Mansoura Faculty of Education, 49, 77-102.

Nassar, F. (2004). The effect of multiple intelligences theory based activities on improving primary pupils English spelling. Unpublished masters' thesis, Faculty of Education. Ain Shams University.

National Institute of Mental Health (NIMH). (1999). Questions and answers. NIMH Multimodal Treatment Study of Children With ADHD. Bethesda, MD: NIMH.

National Institute of Mental Health. (2008). Attention deficit hyperactivity disorder (DHHD Publication No. 08-3572).Washington, DC: U.S. Government Printing Office.

Nevill, M. (2008). The impact of reading self-efficacy and the regulation of cognition on the reading achievement of an intermediate elementary sample. Published doctoral dissertation. Indiana University of Pennsylvania. Retrieved July 16, 2013, from https://dspace.iup.edu/ bitstream/

Olson, E. (2004). Improving the skills of low performing readers in an alternative school program. Published doctoral dissertation. Texas University. Retrieved April 7, 2013, from wwwlib.umi.com/dissertation

Ormrod, J. (2004). Learning theory and the educational process (4th ed.). Boston: Pearson.

Pajares, F. (1996). Self-efficacy beliefs in academic settings. Review of Educational Research, 66, 543-578. 
Pajares, F. (1997). Current directions in self-efficacy research. In M. Maehr \& P. R. Pintrich (Eds.), Advances in motivation and achievement (pp. 1-49). Greenwich, CT: JAI Press.

Pajares, F. (2002). Overview of social cognitive theory and of self-efficacy. Retrieved January 26, 2013, from http://www.emory. edu/EDUCATION/ mfp/

Pajares, F. (2006). Self-efficacy during childhood and adolescence: Implications for teachers and parents. In F. Pajares \& T. Urdan (Eds.), Adolescence and education: Self-efficacy and adolescence (pp. 339-367). Greenwich, CT: Information Age Publishing.

Pajares, F., Johnson, M., \& Usher, E. L. (2007). Sources of writing selfefficacy beliefs of elementary, middle, and high school students. Research in the teaching of English, 42(1), p. 104-121.

Payne, D. (1997). Applied educational assessment. CA: Wadworth Publishing Company.

Perfetti, C., \& Hart, L. (2001). The lexical basis of comprehension skill. In D. Gorein (Ed.), On the consequences of meaning selection: Perspectives on resolving lexical ambiguity (pp. 67-86). Washington, DC: American Psychological Association.

Pijper, N. (2003). The phonological awareness, written spelling and oral reading of learners in an inclusive English-medium education setting. Published masters' thesis, Faculty of Humanities. University of Pretoria. Retrieved July 14, 2013, from www.researchgate.net/237111587_THE

PHONOLOGICAL_AWAREN. 
Preast, S. (2009). A Study of direct instructional spelling strategies and their effect on students with special needs who are classified with mild mental disabilities. Published doctoral dissertation, College of Education, Walden University. Retrieved April 11, 2013, from gradworks.umi. com/33/42/3342450.html

Purdie, N., Hattie, J., \& Carroll, A. (2002). A review of research on interventions for attention deficit hyperactivity disorder: What works best? Review of Educational Research, 72, 61-99.

Rafferty, L. (2010). Step-by-step: Teaching students to self-monitor. Teaching Exceptional Children, 43(2), 50-58.

Rafferty, L. A., \& Raimondi, S. (2009). Self-monitoring of attention versus self-monitoring of performance: Examining the differential effects among students with emotional disturbance engaged in independent math practice. Journal of Behavioral Education, 18, 279-299.

Rafferty, L., Arroyo, J., Ginnane, S., \& Wilczynski, K. (2011). Selfmonitoring during spelling practice: Effects on spelling accuracy and on-task behavior of three students diagnosed with attention deficit hyperactivity disorder. Behavior Analysis in Practice, 4(1), 37-45.

Reid, R. (1996). Research in self-monitoring with students with learning disabilities: The present, the prospects, the pitfalls. Journal of Learning Disabilities, 29, 317-331.

Reid, R., Trout, A., \& Schartz, M. (2005). Self-regulation interventions for children with attention deficit/hyperactivity disorder. Exceptional Children, 71, 361-377. 
Resnick, R. J. (2005). Attention deficit hyperactivity disorder in teens and adults: They don't all outgrow it. Journal of Clinical Psychology, 61(5), 529-533.

Rossiter, M. (2002). The effects of strategy training on L2 learners. Published doctoral dissertation, University of Alberta, Canada. Retrieved June 29, 2013, from wwwlib.umi.com/dissertation

Rock, M. (2005). Use of strategic self-monitoring to enhance academic engagement, productivity, and accuracy of students with and without exceptionalities. Journal of Positive Behavior Interventions, 7(1), 317.

Rock, M. , \& Thead, B. (2007). The effects of fading a strategic selfmonitoring intervention on students' academic engagement, accuracy and productivity. Journal of Behavioral Education, 16, 389-412.

Rowland, A., Lesesne, C., Abramowitz, A. (2002). The epidemiology of attention-deficit/hyperactivity disorder (ADHD): A public health view. Mental Retardation and Developmental Disabilities. 8, 162170.

Schunk, D. (2001). Social cognitive theory and self-regulated learning. In B. J. Zimmerman \& D. H. Schunk (Eds.), Self-regulated learning and academic achievement: Theoretical perspectives (pp.125-151). Mahwah, NJ: Lawrence Erlbaum.

Schunk, D. H. (2003). Self-efficacy for reading and writing: Influence of modeling, goal setting, and self-evaluation. Reading and Writing Quarterly, 19, 159-172.

Schunk, D., \& Meece, J. (2005). Self-efficacy beliefs of adolescents. New York: Information Age. 
Schunk, D., \& Meece, J. (2006). Self-efficacy development in adolescence. In F. Pajares \& T. Urdan (Eds.), Adolescence and education: Selfefficacy and adolescence (pp. 71-96). Greenwich, CT: Information Age Publishing.

Shaw, E. (2007). The reading and writing self-efficacy beliefs of students with discrepant reading and writing performance. Published doctoral dissertation, Graduate School of Education, Fordham University. Retrieved June 25, 2013, from pqdtopen.proquest.com/pqdtopen/doc/ 304644683.html?FMT=ABS

Shapiro, E., DuPaul, G., \& Bradley-Klug, K. (1998). Self-management as a strategy to improve the classroom behavior of adolescents with ADHD. Journal of Learning Disabilities, 31, 545-561.

Shapiro, E., Durnan, S., Post, E., \& Levinson, T. (2002). Self-monitoring interventions for children and adolescents. In M. R. Shinn, H. M. Walker, \& G. Stoner (Eds.), Interventions for academic and behavior problems II: Preventive and remedial approaches (pp. 913-938). Bethesda, MD: NASP.

Shell, D., Colvin,C., \& Brunng R. (1995). Self-efficacy, attribution, and outcome expectancy mechanisms in reading and writing achievement: grade-level and achievement- level differences. Journal of Educational Psychology, 87(3), 386-393.

Shore, J. (2001). An investigation of multiple intelligences and selfefficacy in the university English as a second language classroom. DAI-A, 62(10), 3323.

Simmons, K. (2007). Improving the spelling skills of elementary students with mild learning and behavior problems: A comparison between an 
explicit rule-based method and traditional method. Published doctoral dissertation, Alabama University. Retrieved June 19, 2013, from etd.auburn.edu/etd/

Smith, C., Pest, H., \& Coomber, J. (2001). Spelling for writing: instructional strategies. Clearinghouse on Reading, English, and Communication (ERIC Document Reproduction No. ED 448 460).

Snow, C., Griffin, P., \& Burns, M. (Eds.) (2005). Knowledge to Support the Teaching of Reading: Preparing Teachers for a Changing World. San Francisco: Jossey-Bass.

Snyder, M., \& Bambara, L. (1997). Teaching secondary students with learning disabilities to self-manage classroom survival skills. Journal of Learning Disabilities, 30, 534-543.

Solati, A., Sazalie, A., \& Che, L. (2008). Patterns of spelling errors in language learners' language: An investigation on Persian learners of English. Retrieved June 27, 2013, from faculty.ksu.edu.sa/74597/Documents/ All_papers.pdf

Templeton, S. \& Morris, D. (2000). Spelling. In M. L. Kamil, P. B. Mosenthal, P. D. Pearson, \& R. Barr (Eds.) Handbook of Reading Research (pp. 525-543). Hillsdale, NJ: Erlbaum.

Templin, S., Guile, T., \& Okuma, T. (2001). Creating a reliable and valid self-efficacy questionnaire and English test to raise learners' L2 achievement via raising their self- efficacy. Paper presented at the annual meeting of the Japanese association for language teaching, (ERIC Document Reproduction Service No. ED466625).

Urdan, T. (1997). Achievement goal theory: Past results, future directions. Advances in Motivation and Achievement, 10, 99-142. 
Vaughn. S., Bos, C., \& Schumm, J. (2000). Teaching exceptional, diverse, and at-risk students in the general education classroom. Boston, MA: Allyn and Bacon.

Volpe, R., DuPaul, G., DiPerna, J., Jitendra, A., Lutz, J., Tresco, K., \& Junod, R. (2006). Attention deficit hyperactivity disorder and scholastic achievement: A model of mediation via academic enablers. School Psychology Review, 35, 47-61.

Walker, J. (2003). The cultivation of student self-efficacy in reading and writing. Reading and Writing Quarterly, 19, 173-187.

Willett, L., \& Gardiner, A. (2009). Testing spelling exploring NAPLAN. Retrieved April 29, 2013, from www.englishliteracyconference.com.au/

Zimmerman, B. (2000). Self-efficacy: An essential motive to learn. Contemporary Educational Psychology, 25, 82-91.

Zimmerman, B., \& Cleary, T. (2006). Adolescents' development of personal agency. In F. Pajares \& T. Urdan (Eds.), Adolescence and education: Self-efficacy and adolescence (pp. 45-69). Greenwich, CT: Information Age Publishing. 